\title{
Bioarchaeology of Past Epidemic- and Famine-Related Mass Burials with Respect to Recent Findings from the Czech Republic
}

\author{
Hana Brzobohatáa ${ }^{*}$, Jan Frolík ${ }^{a}$, Eliška Zazvonilováa,b \\ anstitute of Archaeology of the Czech Academy of Sciences, Letenská 4, 11801 Prague 1, Czech Republic \\ ${ }^{b}$ Department of Anthropology and Human Genetics, Faculty of Science, Charles University in Prague, Viničná 7, 12844 Prague 2, Czech Republic
}

\section{A R T ICLE INFO}

\section{Article history:}

Received: $7^{\text {th }}$ May 2019

Accepted: $23^{\text {rd }}$ July 2019

DOI: http://dx.doi.org/ 10.24916/iansa.2019.1.6

Key words:

bioarchaeology

plague

famine

ancient DNA

Middle Ages

mass burials

\begin{abstract}
$A B S T R A C T$
Irrespective of the reason for breaking usual burial customs, mass graves represent a valuable archive of population data over a short period, and thus offer a vast amount of information for bioarchaeological research. Herein, we present a selective review of research on past epidemic and famine die-offs and of new interdisciplinary approaches in this field of study. We summarize the discoveries of epidemic- and famine-related graves that are temporally and spatially restricted to the medieval/early modern Czech territory, paying special attention to recently unearthed mass burials in Kutná Hora-Sedlec. These burial pits are historically and contextually associated with a famine in the early $14^{\text {th }}$ century and with the Black Death in the mid- $14^{\text {th }}$ century. To our knowledge, they represent the largest set of medieval mass graves not only in the Czech Republic but also on a European scale.
\end{abstract}

\section{Osteoarchaeology of epidemic cemeteries}

Mass burials are reported under different contexts and from all time periods. It represents a method for disposing of human remains when there are too many bodies to contend with at one time. Such graves are typically the result of increased mortality due to epidemic, famine, war, genocide, sacrifice, or natural disaster (Beauchamp, 2012; Fornaciari, 2017). To date, many mass graves have been unearthed throughout Europe both in urban and rural contexts and have mostly been attributed to famines and plague epidemics (McIntyre, 2002; Morgan, 2013; Geber, 2014; Bramanti et al., 2018). The field of archaeology has greatly benefited from studying epidemic graves, not only through the historical knowledge gained but also through gaining further insight into palaeodemographic dynamics and to answer questions pertaining to palaeopathology (Beauchamp, 2012).

Palaeodemographic investigations of past famines have revealed both equal representation of males and females

*Corresponding author. E-mail: brzobohata@arup.cas.cz and gender imbalances involving increased female survival, suggesting their higher resistance (McIntyre, 2002; Morgan, 2013). During periods of chronic starvation, the health status of individuals was affected not only by caloric deprivation but also vitamin and mineral deficiencies that weaken the body and increase susceptibility to infections. Thus, death from infectious diseases (such as typhus or dysentery) was probably more common than dying from hunger per se (Scrimshaw, 1987; Morgan, 2013). Although children are considered to be most vulnerable, food shortages lasting for months or years are likely to cause skeletal manifestations of malnourishment and generic indicators of systemic stress in all members of affected societies (e.g., rickets, porotic orbital lesions, teeth enamel defects, Harris growth arrest lines, periostitis, stunted growth, or vertebral neural canal reduction) (Morgan, 2013; Watts, 2013). It has further been documented that individuals who experienced early life stress were, irrespective of age or sex, likely to be frailer than their peers, and thus were more likely to die during famines (Yaussy et al., 2016; DeWitte and Yaussy, 2017). Regarding the age structure of past starving populations, medieval 
samples have shown an increased mortality in non-adults (Geber, 2014), and chronologically younger datasets indicate increased mortality at both extremes of the age spectrum, i.e. children and in elderly persons (Morgan, 2013).

As for the epidemic mortality, the most lethal killer plague - was not selective for sex and male/female ratios of plague burial grounds did not significantly differ from pre- and post-epidemic cemeteries (Signoli et al., 2002; De Witte, 2009). Less frequently, excess female mortality was documented in both urban and rural contexts (Curtis, Roosen, 2017). Another of the factors explored and potentially impacting plague mortality profiles was ageat-death, and DeWitte (2010a) has shown that older adults showed somewhat higher risks of dying during the epidemic compared to the younger.

In general, two different types of mortality can be found in skeletal assemblages: catastrophic and attritional (Margerison, Knüsel, 2002). A high percentage of infant deaths, a low number of adolescent deaths, and an increasing mortality rate throughout adulthood would be consistent with attritional (normal) mortality, while an increased risk of death occurring in all age categories reflects a short-term catastrophe (Gowland, Chamberlain, 2005). If the population was affected by an epidemic, deceased individuals were often buried in mass graves because there was not the time, nor space to bury them individually. If the epidemic killed people indiscriminately regardless of age and sex, then the mass graves would represent an unbiased sample of the population. However, the results of different studies (e.g. DeWitte, 2010b; Galanaud et al., 2015; Crespo, Lawrenz, 2016) have shown that this is not the case, but rather, that susceptibility to death varies during sudden events such as epidemics, which have been referred to as heterogeneity in frailty (Wood et al., 1992). Recent research has indicated that one of the worst demographic crises, the Black Death, caused selective mortality and removed the frailest of the population (DeWitte, 2016). The concept of frailty, defined as a state of decreased resistance to stressors (Fried et al., 2001), has been discussed in several recent bioarchaeological studies (DeWitte, Wood, 2008; DeWitte, 2010b). Factors typically used to evaluate frailty in epidemiological research are generally not observable in skeletal remains. In archaeological populations, only skeletal and dental indicators of stress indicate pathological conditions in an individual. Marklein et al. (2016) proposed a method based on assessing the frailty of living populations applicable to bioarchaeological populations, the skeletal frailty index (SFI). This method provides a frailty score for everyone in a population based on the presence or absence of 13 skeletal and dental indicators. This method should provide a better understanding of the overall health of past populations rather than simply measuring mortality (Marklein et al., 2016).

Demographic composition and indicators of skeletal stress are essential for better understanding health and mortality. By comparing the prevalence of stress indicators (e.g. cribra orbitalia, linear enamel hypoplasia, periosteal new bone formation) in individuals buried in attritional (normal) and mass graves, the level of stress and risk of death can be determined. Higher prevalence of stress lesions would be expected in mass graves. However, the relationship between stress lesions and mortality is not straightforward, demonstrating the osteological paradox phenomenon (Wood et al., 1992; DeWitte, Stojanowski, 2015). The presence of stress lesions does not necessarily mean that the individual was healthier compared with those without lesions, but rather, some individuals without stress lesions died before the stress was reflected in the skeleton. The most detectable skeletal markers require several weeks to form; thus, we can assume that individuals with lesions must have at least survived this long. Bone is slower to respond to the effects of stress than soft tissue. Therefore, the presence of stress indicators indicates severe or prolonged stress. Instead of comparing the prevalence of skeletal stress indicators, they should be evaluated in terms of mortality and their effect on survivorship (Temple, Goodman, 2014).

In the case of mass graves, cultural or historical context can help to understand whether individuals with a higher prevalence of stress were frailer. Although the demographic composition of a population suffering a disease epidemic differs from that of a non-epidemic population, some factors can influence the age distribution of examined samples. Taphonomic factors that influence infant skeletal remains can make them invisible in the archaeological record, consequently biasing the final distribution. When historical and cultural conditions are unknown and only demographic composition is available as evidence of a demographic crisis, differences in skeletal preservation may distort results to resemble attritional mortality (Margerison, Knüsel, 2002; Kyle et al., 2018). Ageing presents further problems in bioarchaeological research. Poorly preserved skeletons, systematic underestimation of old individuals, or circumstances affecting skeletal aging, are some of the factors that complicate the estimation of age at death of adults (Cave, Oxenham, 2016). Furthermore, inconsistency in the use of age-estimation methods causes problems when comparing burial grounds, or their apparent normal mortality (Bramanti et al., 2018). Nevertheless, by combining methods from social and biological sciences in the study of historical mass graves, we can more thoroughly interpret the information held in the bones and, thanks to this transdisciplinary approach, better reconstruct daily life in times of catastrophes.

\section{Difficulties in retrospectively diagnosing infectious diseases}

Previous studies of ancient disease episodes have largely relied on historical and archaeological data alone, such as skeletons, mummified remains, ancient texts, church records, burial registers, and art works (Mitchell, 2011; Signoli, 2012; Smith et al., 2012). However, the most common infections of these times are osteologically invisible, and written records are often inaccurate. Thus, it is not possible to come to a 
modern biological diagnosis for many past epidemics. By medieval times most of the acute infectious diseases were universal in the Old World and had settled into distinct cycles of epidemics, mainly affecting young children (Crawford, 2007). Considering key environmental and epidemiological factors of medieval towns, nearly all microbial and viral transmission routes were facilitated by poor sanitation conditions, contaminated water, and overpopulation. Although many of the worst pre-industrial epidemics appear to have been caused by the bubonic plague, the range of epidemics that are referred to as "plagues" is much larger (Alfani, Murphy, 2017). The causes of epidemics referred to as "peste" or "pestilential" by contemporaries must be investigated separately because it cannot be assumed that a "plague" in one place was due to the same specific microbial agent as those in other places, even during the Black Death (Carmichael, 2008). In particular, populations weakened by malnutrition/starvation could have easily succumbed to influenza, typhus, dysentery, smallpox, typhoid fever, relapsing fever, or another highly-transmissible pathogen (Smith et al., 2012; Andam et al., 2016; Guellil et al., 2018).

For a long time, the most interesting topic concerning the scholars researching historic epidemic assemblages has been determining the causative organism of the bubonic plague (Beauchamp, 2012). The most likely pathogen to account for the plague epidemics is Yersinia pestis. The actual aetiology of this disease has long been controversial, and a group of researchers have argued in favour of other potential microbial agents of the medieval episodes of great mortality. Alternative hypotheses included Bacillus anthracis (Twigg, 1985), a filovirus, or a pathogen that is now extinct (Scott, Duncan, 2001; Cohn, 2003; Duncan, Scott, 2005). They argued that: the differences between the Black Death and current manifestations of the plague are too great to have the same aetiology (Cohn, 2002); the epidemiological dynamics of the medieval Black Death based on historical records were consistent with a viral pathogen spreading as an aerosol or through direct contact between persons (Bossak, Welford, 2009). Other inconsistencies have been pointed out by sceptics, including those between the clinical and epidemiological characteristics of plagues in historical records and those observed in India in the early $20^{\text {th }}$ century (Scott, Duncan, 2001; Cohn, 2002).

Controversies regarding the cause of the plague were resolved by examining the samples taken from bodies buried during the Second Plague Pandemic $\left(14^{\text {th }}-18^{\text {th }}\right.$ centuries) with molecular biology techniques. Since finding the presence of $Y$. pestis in European plague assemblages, both palaeoimmunological (Bianucci et al., 2009; Kacki et al., 2011) and genetic (e.g. Haensch et al., 2010; Seifert et al., 2013; Spyrou et al., 2016) approaches have been successfully introduced. However, presumptive epidemic victims should also be examined in terms of co-morbidities and co-mortalities of plague contemporaries, because the concurrent presence of a plurality of infectious diseases cannot be excluded (Papagrigorakis et al., 2006; Tran et al., 2011). Such an example has been provided by Tran et al. (2011), who detected DNA from both Y. pestis and Bartonella quintana (causing trench fever) in dental pulp harvested from the same medieval mass grave in Bondy, France. Not only were the microbes detected in the same mass grave, but even in the same individuals. Another problem of retrospective diagnosis was demonstrated in the study of Papagrigorakis et al. (2006) regarding the DNA of the causative agent of the Plague of Athens (430 BC). This epidemic has traditionally been considered to be an outbreak of the bubonic plague. However, contrary to written records, the authors of the study proposed typhoid fever as a probable cause of the mass die-offs.

Much palaeomicrobiological data, while confirming that some burial sites in medieval Europe were plague burial pits, do not help resolve the remaining questions concerning the epidemiology of the Black Death. Vast amounts of the plague literature are therefore focused on the issues of primary reservoirs, disease vectors, and epidemiologic spread, in which there remain significant areas of debate (Gage, Kosoy, 2005; Tran et al., 2011; Yue et al., 2017).

\section{Genetic investigations into the causative pathogens of medieval and early modern mass die-offs}

The most informative method to establish the etiological nature of the ancient infections should be the analysis of ancient DNA (Haensch et al., 2010). DNA techniques targeted at genomic parts of pathogens in human remains are quite expensive and cannot be employed indiscriminately. For this reason, their use should be restricted to burial sites at which there are serious indications of a mortality crisis unconnected to a massacre or act of war (Duday, 2008). Because plague was responsible for the worst mortality crises of the medieval and early modern period (Alfani, Murphy, 2017), Yersinia pestis is the pathogen which has been most frequently collected, sequenced, and studied in a historical context (Andam et al., 2016). While the detection of this pathogen in today's plague victims can be achieved without major difficulties, the detection in ancient samples, such as skeletons, is crucial (Seifert et al., 2013). Despite the relevance of genetic investigations into ancient epidemics, for a long time major breakthroughs have been rare and the field has been subject to recurrent scepticism regarding the authenticity of results, poor precautionary measures, faulty methodology, and possible contamination (Wilbur et al., 2009; Callaway, 2011; Knapp, 2011). However, recent improvements in contamination control, workflow design and the emergence of new sequencing technologies have dramatically shifted the possibilities of the identification of all the ancient pathogens.

In 1998, a nucleic-acid based confirmation of ancient plague was achieved for historically-identified French plague victims dated to $16^{\text {th }}$ and $18^{\text {th }}$ centuries (Drancourt et al., 1998). Later, in 2000, Raoult et al. recovered Y. pestis DNA from the teeth of individuals dug up from the $14^{\text {th }}$ century mass grave in Montpellier, France. Contrary to these early 
successful detections, another team found no trace of plague bacterium DNA in 108 teeth from 61 individuals found in plague pits in France, Denmark and England (including East Smithfield) (Gilbert et al., 2004). Further updating and refinement of molecular investigation techniques has soon brought more informative results and constituted molecularly-supported confirmation for the etiologic agent of plague in mass graves in northern, central and southern Europe (Haensch et al., 2010).

A scientific breakthrough was reached in 2011 with the publication reporting a whole genome sequence of Y.pestis from Black Death victims securely dated to episodes of pestilence-associated mortality in London, England, 13481350 (Bos et al., 2011). The same osteological material (but analysed by Schueneman et al. in 2011) permitted reconstruction of the full pPCP1 virulence-associated plasmid at high coverage. These data revealed that the Black Death in medieval Europe was caused by a variant of $Y$. pestis that may no longer exist, and genetic data carried on its pPCP1 plasmid were not responsible for the epidemiological differences between ancient and modern forms of $Y$. pestis infections. Based on the aforesaid results and the growing body of evidence implicating this bacterium as responsible for the medieval pandemic, the authors believe scientific debates should now shift to addressing the genetic basis of the epidemic's unique characteristics (Schueneman et al., 2011).

Seifert et al. (2013) developed a robust ancient DNA workflow to detect plague bacterium in skeletal remains, consisting of optimized sample preparation in combination with thoroughly validated quantitative screening PCR (polymerase chain reaction) assays. In the ensuing study, the researchers sought to find an answer to one of the most challenging questions concerning the plague: how the pandemic could have continued in Europe for several hundred years. Previous genotyping results suggested that the plague was imported to Europe from Central Asia on at least two occasions by distinct trading routes (Haensch et al., 2010). Seifert et al. (2016) recovered DNA from plague victims from German burial sites spanning a time period of more than 300 years (from $14^{\text {th }}$ to $17^{\text {th }}$ century) and identified at least one genotype which was introduced to Europe in the mid- $14^{\text {th }}$ century and persisted here until the Thirty Years' War (1618-1648). Accordingly, they suggest a model in which $Y$. pestis was introduced to Europe in several waves combined with a long-term persistence of the pathogen in not yet identified reservoirs. The genetic link between the medieval and post-medieval European plague outbreaks and the existence of now-extinct European plague foci were also supported by results of Spyrou et al. (2016). Research on this devastating pathogen is now moving to re-analyses and re-evaluations of previously published genomes and using state-of-the-art bioinformatics methods to revise its phylogeny and transmission dynamics (Namouchi et al., 2018).

\section{Suspected epidemic and famine cemeteries from the Czech territory}

Analysis of osteological assemblages from past catastrophes should cover as many archaeological sites as possible (Castex, 2008). Here, we review several medieval and early modern funerary deposits and plausible archaeological evidence of epidemic- and famine-related mass die-offs from the territory of the current Czech Republic (Figure 1).

Mass graves represent an attractive part of archaeological investigations not only for archaeologists and anthropologists, but also for the general public. However, a deeper archaeological comprehension is still in its infancy. Such findings are usually associated with war events, as a resting place for either the fallen soldiers or civilian casualties. In the Czech territory, cases are commonly dated to the Hussite Wars or the Thirty Years' War. In the Moravian region, the

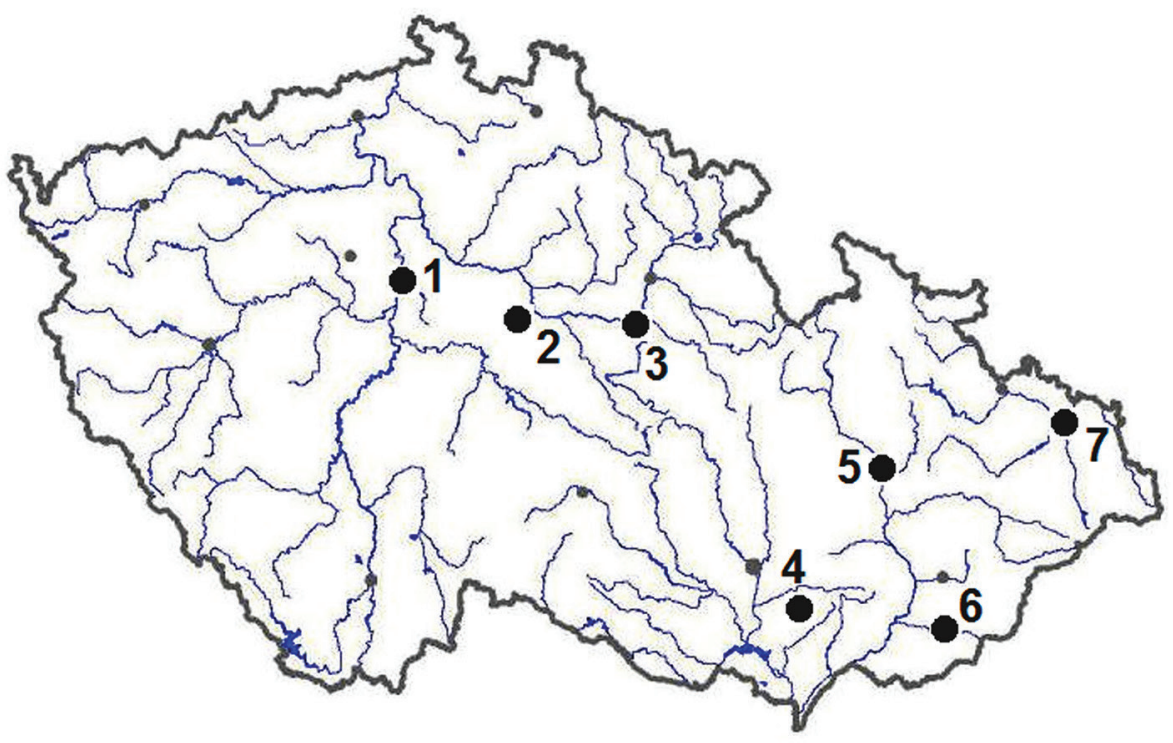

Figure 1. Location of presumed epidemicand famine-related mass graves in the Bohemia and Moravia quoted in the paper: 1 - Prague, Lesser Town, the Church of St. John at the Laundry; 2 - Kutná Hora - Sedlec, Cemetery Church of All Saints with Ossuary; 3 - Pardubice - Pardubičky, extinct Cyriac Monastery; 4 - Boleradice; 5 - Olomouc, the Church of St. Moritz; 6 - Uherský Brod, the Church of Master Jan Hus; 7 - Ostrava, Kostelní Square. 
war with Matthias Corvinus should also be considered. Regarding the non-conflict-related burial pits, there is historical and written evidence for the digging of mass graves during the famines of 1282 (Pokračovatelé Kosmovi, 1974, pp.179-180) and 1318 (Zbraslavská kronika, 1975, p. 317), with precise descriptions of their locations. The reports of plague outbreaks from 1348-1350 are written more generally (Kroniky doby Karla IV., 1987, pp.156, 226, 228), as are reports of later epidemics.

The evidence for these tragic events in the archaeological record is often contradictory and incomplete. Moreover, most of the discovered situations have remained unpublished. Caution in interpreting Czech medieval mass graves as plague pits may be related to the belief that the epidemics of
1348-1350 either did not affect the Czech region or that they were not as devastating as they were elsewhere (see Mengel, 2011 for a review of this problem).

Regarding the Moravian sites, "skeletons in shafts above one another" from Boleradice are believed to be associated with the plague epidemic of the $17^{\text {th }}$ century (Poulík, 1948, p.148). Mass burials from Ostrava (Kostelní Square), Olomouc (Church of St. Moritz), and Uherský Brod (Church of Master Jan Hus) can generally be interpreted as a result of unknown medieval or early-modern epidemics (Živný, 2005, pp.124, 286). There are also problems with dating, because many mass graves cannot be precisely dated, and are thus difficult to attribute to specific events (Belcredi, 1998). In Bohemia a plague-related mass grave has been discovered

Figure 2. View of one of 32 mass graves excavated next to the Church of All Saints with Ossuary in Kutná Hora - Sedlec, Czech Republic.

Figure 3. Child cadaver deposited in the pit corner to effectively use the space in the tomb (skeleton No. 540, child, 6-8 years old, the Church of All Saints with Ossuary in Kutná Hora - Sedlec, Czech Republic).
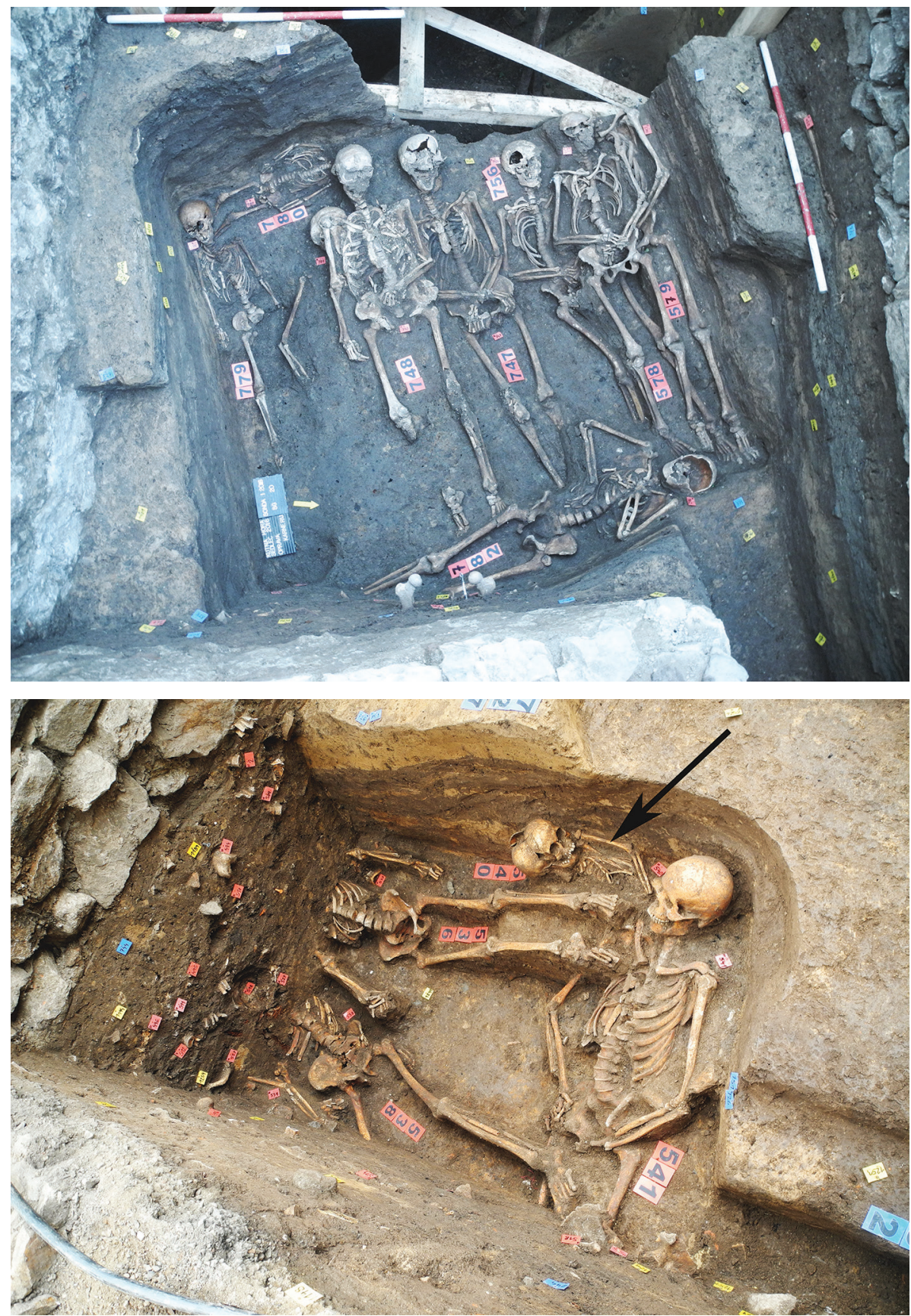

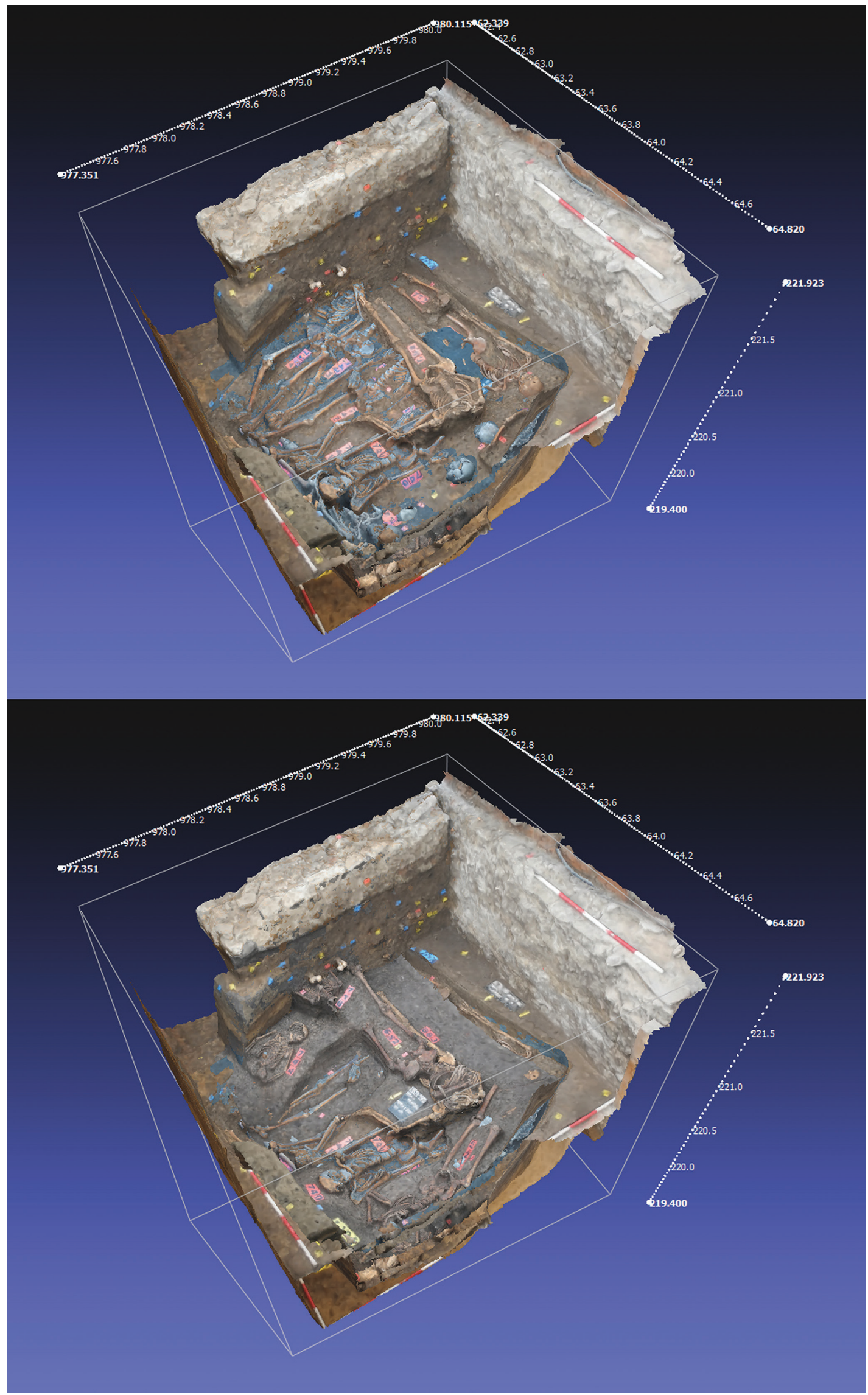

Figure 4. Three-dimensional visualisation of a mass grave showing the grave construction, arrangement of the bodies, and burial sequences, the Church of All Saints with Ossuary in Kutná Hora - Sedlec, Czech Republic. 
at the Church of St. John at the Laundry in the Lesser Town of Prague. Coins found in the vicinity of one of the cadavers allowed the pit to be dated to circa 1597 (Nohejlová-Prátová, 1940; Klápště, 1999). Archaeological excavation carried out in an old monastery in Pardubice-Pardubičky revealed a mass burial, which, based on the coins, can be connected with "some plague outbreak, e.g. in 1358, or some epidemic or famine of local character" (Šebek, 2018). In all the abovementioned cases, no anthropological analyses have been conducted and no bioarchaeological approaches have been applied to support the interpretations. On top of that, it can be assumed that most of the osteological material has been lost and is no longer available (e.g. skeletons recovered at the Church of St. John at the Laundry or bones from Boleradice). Despite this, new findings from the region provide a possible starting point for future research.

The recent discovery of 32 (complete and incomplete) mass burials in the vicinity of the Cemetery Church of All Saints with Ossuary in Kutná Hora, Sedlec (Figure 2), uniquely demonstrates large-scale mass mortality during well-defined periods (Frolík, 2017a; 2017b; 2018; in press). In the graveyard surrounding the church with ossuary, both individual and mass graves were found (32 mass graves with circa 1200 skeletons and circa 600 individual graves) (Figure 2). The chronology of mass graves at the ossuary is based on the favourable stratigraphic situation with two levels of catastrophe-related pits. The younger stratigraphic level has been damaged by the ossuary walls. Assigning the younger graves to the victims of the plague epidemic that hit the Czech lands in 1348-1350 is based on finding Prague groschen-type coins of the Czech King John of Luxembourg (1310-1346) in two graves. In one case, these are the last mintings of this king dated to 1346. Other dates, such as connecting it with younger plague outbreaks, can be excluded because the ossuary was constructed before 1400 (Poche, 1980, p.302; Chadraba, 1984, p.200). We linked the older level of the mass graves with the report of the Zbraslav Chronicle (Zbraslavská kronika, 1975, p.317) in 1318 on the famine and burial of its victims in front of the gates of Sedlec in Kutná Hora. Despite the catastrophic circumstances and large number of deceased, these mass graves exhibit the respectful and deliberate treatment of the dead. Corpses were laid out in a supine position within rectangular pits in several cross-stacked layers (Figure 3), and child cadavers were placed in the pit corners to effectively use the space of the tomb (Figure 4).

To our knowledge, the recently discovered Kutná HoraSedlec graves represent the largest set of medieval mass graves in the Czech Republic and probably Europe. These are valuable population samples dated to short periods, and thus offer a huge amount of information crucial to bioarchaeological research. Digitalized models of selected bones from the Kutná Hora-Sedlec burial ground have already been used in a pilot study of human tibial curvature, through which we have acquired data on the lower limb loading at this time (Brzobohatá et al., 2019). During both crises, burial procedures accelerated to a degree, while cultural filters of burial treatment disappeared and could not have deformed the composition of the resultant funerary deposit. It is therefore possible to gain further understanding of the lives and living conditions of the inhabitants of medieval Kutná Hora.

\section{Conclusions}

Mass burials from past periods of famine or at the peak of epidemics provide unique skeletal remains that provide important insights into these mortality crises, which can occasionally be corroborated by written records. Examining human remains and interpreting past mortality crises requires thorough, complementary, and multidisciplinary approaches. The archaeological demonstration of an abrupt mortality crisis is generally possible only when inhumations take place inside structures in which the remains of a large number of people are accumulated within a constrained space. An example of such a mass synchronous deposition of cadavers was recently excavated in Kutná Hora-Sedlec, offering vast bioarchaeological data with desirable temporal and spatial restriction. As more historical mass burials are excavated and more analyses conducted, we will gain a broader understanding of burial practices during catastrophic events and also of the lives and lifestyles of the victims.

\section{Acknowledgments}

This work was accomplished with institutional support of internal projects ARU-G - RVO: 67985912.

\section{References}

ALFANI, G., MURPHY, T.E., 2017. Plague and Lethal Epidemics in the Pre-Industrial World. The Journal of Economic History, 77, 314-343.

ANDAM, C.P., WORBY, C.J., CHANG, Q., CAMPANA, M.G., 2016. Microbial genomics of ancient plagues and outbreaks. Trends in Microbiology, 24, 978-990.

BEAUCHAMP, A., 2012. The Black Death, plague, and mass mortality. Journal of the University of Manitoba Anthropology Students Association, 30, 1-16.

BELCREDI, L., 1998. Komenda řádu německých rytírů ve Slavkově u Brna. Pravék (Nová řada), 8, 341-367.

BIANUCCI, R., RAHALISON, L., PELUSO, A., MASSA, E.R., FERROGLIO, E., et al., 2009. Plague immunodetection in remains of religious exhumed from burial sites in central France. Journal of Archaeological Science, 36, 616-621.

BOS, K.I., SCHUENEMANN, V.J., GOLDING, G.B., BURBANO, H.A., WAGLECHNER N., et al.. 2011. A draft genome of Yersinia pestis from victims of the Black Death. Nature, 478, 506-510.

BOSSAK, B.H., WELFORD, M.R., 2009. Did medieval trade activity and a viral etiology control the spatial extent and seasonal distribution of Black Death mortality? Medical Hypotheses, 72, 749-752.

BRAMANTI, B., ZEDDA, N., RINALDO, N., GUALDI-RUSSO, E., 2018. A critical review of anthropological studies on skeletons from European plague pits of different epochs. Scientific Reports, 8, 17655.

BRZOBOHATÁ, H., KRAJÍČEK, V., VELEMÍNSKÝ, P., VELEMÍNSKÁ, J., 2019. Three-dimensional geometry of human tibial anterior curvature 
in chronologically distinct population samples of Central Europeans (2900 BC - 21st century AD). Scientific Reports, 9, 4234.

CALLAWAY, E., 2011. Plague genome: The Black Death decoded. Nature, 478, 444-446.

CARMICHAEL, A.G., 2008. Universal and particular: The language of plague, 1348-1500. Medical History, 52, 17-52.

CASTEX, D., 2008. Identification and Interpretation of Historical Cemeteries Linked to Epidemics. In: D. Raoult and M. Drancourt, eds. Paleomicrobiology: Past Human Infections. Berlin, Heidelberg: Springer, pp. 23-48.

CAVE, C., OXENHAM, M., 2016. Identification of the archaeological "invisible elderly": an approach illustrated with an Anglo-Saxon example. International Journal of Osteoarchaeology, 26, 163-175.

CHADRABA, R., 1984. Dějiny českého výtvarného umění I/1. Od počátku do konce středověku. Praha: Academia.

COHN, S.K., 2002. The Black Death: End of a Paradigm. American Historical Review, 107, 703-738.

COHN, S.K., 2003. The Black Death transformed: disease and culture in early renaissance Europe. London: Bloomsbury Academic.

CRAWFORD, D.H., 2007. Deadly companions: how microbes shaped our history. Oxford: Oxford University Press.

CRESPO, F., LAWRENZ, M.B., 2016. Heterogeneous immunological landscapes and medieval plague: an invitation to a new dialogue between historians and immunologists. The Medieval Globe, 1, 229-257.

CURTIS, D.R., ROOSEN, J., 2017. The sex-selective impact of the Black Death and recurring plagues in the Southern Netherlands, 1349-1450. American Journal of Physical Anthropology, 164, 246-259.

DEWITTE, S.N., 2009. The effect of sex on risk of mortality during the Black Death in London, A.D. 1349-1350 American Journal of Physical Anthropology, 139, 222-234.

DEWITTE, S.N., 2010a. Age patterns of mortality during the Black Death in London, AD 1349-1350. Journal of Archaeological Science, 37, 3394-3400.

DEWITTE, S.N., 2010b. Sex differentials in frailty in medieval England. American Journal of Physical Anthropology, 143, 285-297.

DEWITTE, S.N., 2016. The anthropology of plague: insights from bioarcheological analyses of epidemic cemeteries. The Medieval Globe 1 , article 6 .

DEWITTE, S.N., STOJANOWSKI, C.M., 2015. The osteological paradox 20 years later: past perspectives, future directions. Journal of Archaeological Research, 23, 397-450.

DEWITTE, S.N., YAUSSY, S.L., 2017. Short femur length and famine mortality in medieval London. Bioarchaeology International, 1, 171182.

DEWITTE, S.N., WOOD, J.W., 2008. Selectivity of Black Death mortality with respect to preexisting health. Proceedings of the National Academy of Sciences, 105, 1436-1441.

DRANCOURT, M., ABOUDHARAM, G., SIGNOLI, M., DUTOUR, O., RAOULT, D., 1998. Detection of 400-year-old Yersinia pestis DNA in human dental pulp: An approach to the diagnosis of ancient septicemia. Proceedings of National Academy of Sciences of the USA, 95, 1263712640.

DUNCAN, C.J., SCOTT, S., 2005. What caused the Black Death? Postgraduate Medical Journal, 81, 315-320.

DUDAY, H., 2008. Archaeological proof of an abrupt mortality crisis: simultaneous deposit of cadavers, simultaneous deaths? In: D. Raoult and M. Drancourt, eds. Paleomicrobiology: Past Human Infections. Berlin, Heidelberg: Springer, pp. 49-54.

FORNACIARI, A., 2017. Environmental microbial forensics and archaeology of past pandemics. Microbiology Spectrum, 5, e0011-2016.

FRIED, L.P., TANGEN, C.M., WALSTON, J., NEWMAN, A.B., HIRSCH, C., et al. 2001. Frailty in older adults: evidence for a phenotype. The Journals of Gerontology Series A: Biological Sciences and Medical Sciences, 56, 146-157.

FROLÍK, J., 2017a. Pohřbívání ve vrcholném středověku a v novověku na Chrudimsku, Pardubicku a Kolínsku - Bestattungen im Hochmittelalter und in der Neuzeit in den Regionen Chrudim, Pardubice und Kolín. Archaeologia historica, 42, 187-205.

FROLÍK, J., 2017b. Záchranný archeologický výzkum při odvodnění hřbitovního kostela Všech Svatých s kostnicí v Kutné Hoře - Sedlci Archäologische Retunggrabung bei der Entwässerung des Beinhauses in
Kutná Hora-Sedlec. Zprávy ČAS-Supplément, 105, 34-35.

FROLÍK, J., 2018. Pokračování záchranného archeologického výzkumu u hřbitovního kostela Všech Svatých s kostnicí v Kutné Hoře-Sedlci - Forsetzung der archäologischen Rettungsgrabung bei der KirchhofAllerheiligenkirche mit dem Beinhaus in Kutná Hora/Kuttenberg-Sedlec. Zprávy ČAS-Supplément, 109, 35-36.

FROLÍK, J., (in press). Dokončení záchranného archeologického výzkumu u hřbitovního kostela Všech Svatých s kostnicí v Kutné Hoře - Sedlci. Zprávy ČAS - Supplément.

GAGE, K.L., and KOSOY, M.Y., 2005. Natural history of plague: perspectives from more than a century of research. Annual Review of Entomology, 50, 505-528.

GALANAUD, P., GALANAUD, A., GIRAUDOUX, P., 2015. Historical epidemics cartography generated by spatial analysis: mapping the heterogeneity of three medieval "plagues" in Dijon. PloS ONE, 10, e0143866.

GEBER, J., 2014. Skeletal manifestations of stress in child victims of the Great Irish Famine (1845-1852): prevalence of enamel hypoplasia, Harris lines, and growth retardation. American Journal of Physical Anthropology, 155, 149-161.

GILBERT, M.T.P., CUCCUI, J., WHITE, W., LYNNERUP, N., TITBALL, R.W. et al., 2004. Absence of Yersinia pestis-specific DNA in human teeth from five European excavations of putative plague victims. Microbiology, $150,341-354$.

GOWLAND, R., CHAMBERLAIN, A.T., 2005. Detecting plague: paleodemographic characterisation of a catastrophic death assemblage. Antiquity, 79, 146-157.

GUELLIL, M., KERSTEN, O., NAMOUCHI, A., BAUER, E.L., DERRICK, M. et al., 2018. Genomic blueprint of a relapsing fever pathogen in $15^{\text {th }}$ century Scandinavia. Proceedings of National Academy of Sciences of the USA, 115, 10422-10427.

HAENSCH, S., BIANUCCI, R., SIGNOLI, M., RAJERISON, M., SCHULTZ, M. et al., 2010. Distinct clones of Yersinia pestis caused the Black Death. PLOS Pathogens, 6, e1001134.

KACKI, S., RAHALISON, L., RAJERISON, M., FERROGLIO, E., BIANUCCI, R., 2011. Black Death in the rural cemetery of SaintLaurent-de-la-Cabrerisse Aude-Languedoc, southern France, $14^{\text {th }}$ century: immunological evidence. Journal of Archaeological Science, 38, 581-587.

KLÁPŠTĚ, J., 1999. Př́spěvek k archeologickému poznávání úlohy mince v přemyslovských Čechách - Ein Beitrag zur archäologischen Erforschung der Rolle der Münzen im Přemysliden Böhmen. Archeologické rozhledy 51, 774-808.

KNAPP, M., 2011. The next generation of genetic investigations into the Black Death. Proceedings of National Academy of Sciences of the USA, 108, 15669-15670.

KRONIKY DOBY KARLA IV., 1987. Kroniky doby Karla IV. Praha: Svoboda.

KYLE, B., REITSEMA, L.J., TYLER, J., FABBRI, P.F., VASSALLO, S., 2018. Examining the osteological paradox: skeletal stress in mass graves versus civilians at the Greek colony of Himera (Sicily). American Journal of Physical Anthropology, 167, 161-172.

MARGERISON, B.J., KNÜSEL, C.J., 2002. Paleodemographic comparison of a catastrophic and an attritional death assemblage. American Journal of Physical Anthropology, 119, 134-143.

MARKLEIN, K.E., LEAHY, R.E., CREWS, D.E., 2016. In sickness and in death: assessing frailty in human skeletal remains. American Journal of Physical Anthropology, 161, 208-225.

MCINTYRE, K., 2002. Famine and the female mortality advantage. In: T. Dyson, C.O. Grada, eds. Famine demography: perspectives from the past and present. Oxford: Oxford University Press, pp. 240-259.

MENGEL, D.C., 2011. A Plague in Bohemia? Mapping the Black Death. Past \& Present, 211, 3-34.

MITCHELL, P.D., 2011. Retrospective diagnosis and the use of historical texts for investigating disease in the past. International Journal of Paleopathology, 1, 81-88.

MORGAN, J., 2013. The invisible hunger: is famine identifiable from the archaeological record? Antrocom Online Journal of Anthropology, 9, $115-129$.

NAMOUCHI, A., GUELliL, M., KERSTEN, O., HAENSCH, S., OTTONI, C. et al., 2018. Integrative approach using Yersinia pestis 
genomes to revisit the historical landscape of plague during the Medieval Period. Proceedings of National Academy of Sciences of the USA, 115, e11790-11797.

NOHEJLOVÁ-PRÁTOVÁ, E., 1940. Nález u sv. Jana na Prádle v Praze III. Numismatický časopis, 15, 83-84.

PAPAGRIGORAKIS, M.J., YAPIJAKIS, C., SYNODINOS, P.N., BAZIOTOPOULOU-VALAVANI, E., 2006. DNA examination of ancient dental pulp incriminates typhoid fever as a probable cause of the Plague of Athens. International Journal of Infectious Diseases, 10, 206-214.

POCHE, E., 1980. Umélecké památky Čech 3 P/Š. Praha: Academia.

POKRAČOVATELÉ KOSMOVI, 1974. Pokračovatelé Kosmovi. Praha: Svoboda.

POULÍK, J., 1948. Staroslovanská Morava - Morava in Old SlavonicPeriod. Praha: Státní archeologický ústav.

RAOULT, D., ABOUDHARAM, G., CRUBEZY, E., LARROUY, G., LUDES, B., DRANCOURT, M., 2000. Molecular identification by "suicide PCR" of Yersinia pestis as the agent of Medieval Black Death Proceedings of National Academy of Sciences of the USA, 97, 12800 12803.

SCHUENEMANN, V.J., BOS, K., DEWITTE, S., SCHMEDES, S., JAMIESON, J. et al., 2011. Targeted enrichment of ancient pathogens yielding the pPCP1 plasmid of Yersinia pestis from victims of the Black Death. Proceedings of National Academy of Sciences of the USA, 108 746-752.

SCRIMSHAW, N.S., 1987. The phenomenon of famine. Annual Review of Nutrition, 7, 1-21.

SCOTT, S., DUNCAN, C.J., 2001. Biology of plagues. Cambridge: Cambridge University Press.

SEIFERT, L., HARBECK, M., THOMAS, A., HOKE, N., ZÖLLER, L., et al., 2013. Strategy for sensitive and specific detection of Yersinia pestis in skeletons of the Black Death pandemic. PLOS ONE, 8, e75742.

SEIFERT, L., WIECHMANN, I., HARBECK, M., THOMAS, A., GRUPE G., et al. 2016. Genotyping Yersinia pestis in historical plague: evidence for long-term persistence of $Y$. pestis in Europe from the $14^{\text {th }}$ to the $17^{\text {th }}$ century. PLOS ONE, 11, e0145194.

SIGNOLI, M., 2012. Reflections on crisis burials related to past plague epidemics. Clinical Microbiology and Infection, 18, 218-223.

SIGNOLI, M., SÉGUY, I., BIRABEN, J.N., DUTOUR, O., 2002. Paleodemography and historical demography in the context of an epidemic. Population, 57, 829-854.
SMITH, P.W., WATKINS, K., HEWLETT, A., 2012. Infection control through the ages. American Journal of Infection Control, 40, 35-42.

SPYROU, M.A., TUKHBATOVA, R.I., FELDMAN, M., DRATH, J., KACKI, S. et al., 2016. Historical Y. pestis genomes reveal the European Black Death as the source of ancient and modern plague pandemics. Cell Host \& Microbe, 19, 874-881.

ŠEBEK, F., 2018. Spor o nejstarší dějiny Pardubic-ADispute of Pardubice's Earliest History. Východočeský sborník historický, 34, 153-195.

TEMPLE, D.H., GOODMAN, A.H., 2014. Bioarcheology has a "health" problem: Conceptualizing "stress" and "health" in bioarchaeological research. American Journal of Physical Anthropology, 155, 186-191.

TRAN, T.N., FORESTIER, C.L., DRANCOURT, M., RAOULT, D., ABOUDHARAM, G., 2011. Brief communication: co-detection of Bartonella quintana and Yersinia pestis in an $11^{\text {th }}-15^{\text {th }}$ burial site in Bondy, France. American Journal of Physical Anthropology, 145, 489494.

TWIGG, G., 1985. The Black Death: a biological reappraisal. New York: Schocken Books.

WATTS, R., 2013. Lumbar vertebral canal size in adults and children: observations from a skeletal sample from London, England. HOMO, 64 , $120-128$.

WILBUR, A.K., BOUWMAN, A.S., STONE, A.C., ROBERTS, C.A., PFISTER, L.A. et al., 2009. Deficiencies and challenges in the study of ancient tuberculosis DNA. Journal of Archaeological Science, 36, 1990-1997.

WOOD, J.W., MILNER, G.R., HARPENDING, H.C., WEISS, K.M., COHEN, M.N. et al., 1992. The osteological paradox: problems of inferring prehistoric health from skeletal samples. Current Anthropology, 33, 343-370.

YAUSSY, S.L., DEWITTE, S.N., REDFERN, R.C., 2016. Frailty and famine: patterns of mortality and physiological stress among victims of famine in medieval London. American Journal of Physical Anthropology, 160, 272-283.

YUE, R.P., LEE, H.F., WU, C.Y., 2017. Trade routes and plague transmission in pre-industrial Europe. Scientific Reports, 7, 12973.

ZBRASLAVSKÁ KRONIKA, 1975. Zbraslavská kronika - Chronicon Aulae Regiae. Praha: Svoboda.

ŽIVNÝ, M., 2005. Pohřební ritus na Moravě v 11. - 15. století ve středoevropském kontextu. Unpublished thesis (PhD), Masaryk University in Brno. 
